\title{
Expression of GATA-2 in Human Pituitary Adenomas
}

\author{
Katsuya Umeoka, Naoko Sanno, R. Yoshiyuki Osamura, Akira Teramoto
}

Department of Neurosurgery (KU, NS, AT), Nippon Medical School, Tokyo, Japan; and Department of

Pathology (RYO), Tokai University School of Medicine, Kanagawa, Japan

Transcription factor GATA-2 contains two copies of a highly conserved zinc finger domain and plays unique roles at an early stage of hematopoietic differentiation. In the mouse pituitary gland, Pit-1GATA-2 protein-protein interaction has been shown to lead to gene-specific actions to obtain cell-specific roles. In this study, we investigated the expression of GATA-2 and Pit-1 in human pituitary adenomas using reverse transcription polymerase chain reaction (RT-PCR) and immunohistochemical techniques. By immunohistochemical analysis, GATA-2 was detected in all of the gonadotropinsubunit (Gn-su)-positive adenomas $(n=8)$ and in four of five thyroid-stimulating hormone (TSH)secreting adenomas, but its incidence was low in the other types of adenomas. Pit-1 protein was detected in 4 of 5 TSH-secreting adenomas and in 10 of 10 growth hormone (GH)-secreting adenomas. By RTPCR analysis, GATA-2 was detected in all Gn-supositive adenomas and TSH-secreting adenomas, and Pit-1 was detected in all TSH-secreting adenomas and GH-secreting adenomas. These results suggested that GATA-2 contributes to the functional expression and the differentiation of Gn-su-positive adenomas and the TSH-secreting adenomas and that the interaction between GATA-2 and Pit-1 can lead to gene-specific action and differentiation of TSH-secreting adenomas. It is further speculated that GATA-2 and transcriptional interaction with Pit-1 play roles in the functional differentiation of specific pituitary adenomas.

KEY WORDS: GATA-2, Imunohistochemistry, Pit-1, Pituitary adenoma, RT-PCR, Transcription factor.

Mod Pathol 2002;15(1):11-17

Copyright (C) 2002 by The United States and Canadian Academy of Pathology, Inc.

VOL. 15, NO. 1, P. 11, 2002 Printed in the U.S.A.

Date of acceptance: September 27, 2001.

Address reprint requests to: R. Yoshiyuki Osamura, Department of Pathology, Tokai University School of Medicine, Isehara-City, Kanagawa, 259-

1193, Japan; e-mail: osamura@is.icc.u-tokai.ac.jp; fax: 81-463-91-1370.
The pituitary gland is initially derived from the Rathke's pouch, and its primordium appears on e8.5 in mouse (1). It has been demonstrated that direct contact of the ventral diencephalons with Rathke's pouch is required for pituitary organogenesis and that pituitary cell type determination occurs in response to a series of extrinsic and intrinsic signaling molecules (2-4).

Several transcription factors have been identified in the adenohypophysis and have been implicated as key elements in the definition of cell-specific phenotypes and regulation of hormone gene expression. For example, the pituitary-specific transcription factor Pit-1, a member of a family of the POU-domain DNA-binding factors, has been shown to regulate growth hormone (GH), prolactin (PRL), and thyroid-stimulating hormone (TSH) cells during development and differentiation (5-12). Neuro D1, a basic helix-loop-helix transcription factor, is expressed in corticotroph cells and contributes to the corticotroph-specific POMC transcription in the pituitary $(13,14)$. Although the mechanisms of functional expression toward $\mathrm{GH}$, PRL, TSH, and ACTH have been investigated in details with pituitary glands, its mechanisms accounting for gonadotroph differentiation remained unclear until it was recently demonstrated that GATA-2, zinc finger transcription factor, is necessary for the differentiation and determination of gonadotrophs and thyrotrophs in mouse (15). In addition, GATA- 2 has been shown to regulate the human gonadotropin $\alpha$-subunit gene in the placenta and pituitary gland (16) and also to have activated the mouse thyrotropin $\beta$-subunit promoter (17). These data have led us to hypothesize that GATA-2 is another transcription factor involved in cell-specific hormone expression in human pituitary adenoma. Therefore, to understand the role of GATA-2 in the functional differentiation and biological behavior in pituitary adenomas, we analyzed the expression of GATA-2 in various types of human pituitary adenomas using the immunohistochemical techniques and reverse transcription polymerase chain reaction (RT-PCR) method. Moreover, we evaluated the relation between 
GATA-2 and Pit-1 expression in the functional differentiation of the pituitary adenomas.

\section{MATERIALS AND METHODS}

\section{Tissues}

The tissues from 38 cases of pituitary adenomas (21 cases from men, 17 cases from women; age ranged from 19 to $71 \mathrm{y}$ ) were obtained at the time of transsphenoidal surgery. The clinical and endocrinological features were as follows: $10 \mathrm{GH}$-secreting adenomas with symptoms of acromegaly, 6 PRLsecreting adenomas in which serum PRL levels ranged from 150 to $1860 \mathrm{ng} / \mathrm{mL}, 4 \mathrm{ACTH}$-secreting adenomas with typical Cushing's syndrome, 5 TSHsecreting adenomas with hyperthyroidism, 5 nonfunctioning adenomas without clinical evidence of anterior pituitary hormone excess or without high serum concentration of anterior pituitary hormone except mild hyperprolactinemia $(<100 \mathrm{ng} / \mathrm{mL})$, and $8 \mathrm{Gn}$-su-positive adenomas by immunohistochemistry. Serum follicle-stimulating hormone (FSH) of Gn-su-positive adenomas was elevated in all male cases. Tumor types were classified based on their clinical manifestations, biological functions, and ultrastructures (18). Table 1 indicates the clinical and biochemical features of 38 pituitary adenomas. The tissues were submitted to the following RT-PCR and immunohistochemical studies.

\section{Immunohistochemical Examination}

The tissues from pituitary adenomas were routinely fixed in $10 \%$ formalin for 8 to 24 hours and embedded in paraffin. Five-micrometer serial sections attached to silane-coated slides were deparaffinized in xylene and dehydrated in graded ethanols to phosphate buffered saline, $\mathrm{pH}$ 7.4. Endogenous peroxidase activity was blocked with $0.3 \%$ hydrogen peroxide in methanol for $30 \mathrm{~min}$ utes. Immunostaining was performed using the avidin-biotin-peroxidase complex (ABC) technique. Immunostaining for GATA-2 was detected as followed, the sections were treated by autoclave for 3 minutes at $120^{\circ} \mathrm{C}$ in $0.01 \mathrm{~mol} / \mathrm{L}$ citrate buffer, $\mathrm{pH}$ 6.0, for antigen retrieval, and goat anti-GATA-2

TABLE 1. Clinical and Biochemical Feature in a Total of 38 Pituitary Adenomas

\begin{tabular}{|c|c|c|c|}
\hline Diagnosis & Case No. & Age $(y) /$ Sex & Biochemical Feature \\
\hline \multirow[t]{10}{*}{ Acromegaly } & 1 & $38 / \mathrm{F}$ & $\mathrm{GH}, 5.0 \mathrm{ng} / \mathrm{mL}$; IGF-1, $340 \mathrm{ng} / \mathrm{mL}$ \\
\hline & 2 & $59 / F$ & $\mathrm{GH}, 33.8 \mathrm{ng} / \mathrm{mL} ; \mathrm{IGF}-1,960 \mathrm{ng} / \mathrm{mL}$ \\
\hline & 3 & $45 / F$ & $\mathrm{GH}, 12.4 \mathrm{ng} / \mathrm{mL}$ IGF-1, $110 \mathrm{ng} / \mathrm{mL}$ \\
\hline & 4 & $46 / \mathrm{M}$ & $\mathrm{GH}, 24.4 \mathrm{ng} / \mathrm{mL}$; IGF-1, $1340 \mathrm{ng} / \mathrm{mL}$ \\
\hline & 5 & $48 / \mathrm{F}$ & $\mathrm{GH}, 40.6 \mathrm{ng} / \mathrm{mL} ; \mathrm{IGF}-1,12500 \mathrm{ng} / \mathrm{mL}$ \\
\hline & 6 & $30 / \mathrm{M}$ & $\mathrm{GH}, 17.2 \mathrm{ng} / \mathrm{mL} ; \mathrm{IGF}-1,680 \mathrm{ng} / \mathrm{mL}$ \\
\hline & 7 & $52 / \mathrm{M}$ & $\mathrm{GH}, 10.3 \mathrm{ng} / \mathrm{mL} ; \mathrm{IGF}-1,890 \mathrm{ng} / \mathrm{mL}$ \\
\hline & 8 & $35 / \mathrm{F}$ & $\mathrm{GH}, 9.5 \mathrm{ng} / \mathrm{mL} ; \mathrm{IGF}-1,770 \mathrm{ng} / \mathrm{mL}$ \\
\hline & 9 & $55 / \mathrm{M}$ & $\mathrm{GH}, 15.7 \mathrm{ng} / \mathrm{mL} ; \mathrm{IGF}-1,320 \mathrm{ng} / \mathrm{mL}$ \\
\hline & 10 & $51 / \mathrm{M}$ & $\mathrm{GH}, 22.2 \mathrm{ng} / \mathrm{mL} ; \mathrm{IGF}-1,750 \mathrm{ng} / \mathrm{mL}$ \\
\hline \multirow{6}{*}{ PRL-secreting adenomas } & 1 & $20 / F$ & PRL, 369.6 ng/mL \\
\hline & 2 & $19 / \mathrm{M}$ & PRL, $770.8 \mathrm{ng} / \mathrm{mL}$ \\
\hline & 3 & $23 / \mathrm{F}$ & PRL, $175.8 \mathrm{ng} / \mathrm{mL}$ \\
\hline & 4 & $31 / \mathrm{M}$ & PRL, 3788.2 ng/mL \\
\hline & 5 & $24 / \mathrm{F}$ & PRL, $2135.9 \mathrm{ng} / \mathrm{mL}$ \\
\hline & 6 & $37 / \mathrm{F}$ & PRL, $422.4 \mathrm{ng} / \mathrm{mL}$ \\
\hline \multirow[t]{4}{*}{ Cushing's } & 1 & $55 / \mathrm{M}$ & ACTH, $130 \mathrm{pg} / \mathrm{mL}$; UFC, $1852 \mu \mathrm{g} /$ day \\
\hline & 2 & $28 / F$ & ACTH, $2600 \mathrm{pg} / \mathrm{mL}$; UFC, $952 \mu \mathrm{g} /$ day \\
\hline & 3 & $44 / \mathrm{F}$ & ACTH, $130 \mathrm{pg} / \mathrm{mL} ; \mathrm{UFC}, 1115 \mu \mathrm{g} /$ day \\
\hline & 4 & $29 / \mathrm{M}$ & ACTH, $630 \mathrm{pg} / \mathrm{mL}$; UFC, $897 \mu \mathrm{g} /$ day \\
\hline \multirow[t]{5}{*}{ TSH-secreting adenomas } & 1 & $53 / \mathrm{F}$ & $\mathrm{fT}_{3}, 3.6 \mathrm{pg} / \mathrm{mL} ; \mathrm{fT}_{4}, 1.54 \mathrm{pg} / \mathrm{mL}, \mathrm{TSH}, 11.3 \mu \mathrm{U} / \mathrm{mL}$ \\
\hline & 2 & $41 / \mathrm{M}$ & $\mathrm{fT}_{3}, 6.2 \mathrm{pg} / \mathrm{mL} ; \mathrm{fT}_{4}, 2.19 \mathrm{pg} / \mathrm{mL}, \mathrm{TSH}, 1.8 \mu \mathrm{U} / \mathrm{mL}$ \\
\hline & 3 & $35 / F$ & $\mathrm{fT}_{3}, 3.8 \mathrm{pg} / \mathrm{mL} ; \mathrm{fT}_{4}, 1.48 \mathrm{pg} / \mathrm{mL}, \mathrm{TSH}, 5.05 \mu \mathrm{U} / \mathrm{mL}$ \\
\hline & 4 & $28 / \mathrm{F}$ & $\mathrm{fT}_{3}, 8.62 \mathrm{pg} / \mathrm{mL} ; \mathrm{fT}_{4}, 3.15 \mathrm{pg} / \mathrm{mL}, \mathrm{TSH}, 3.21 \mu \mathrm{U} / \mathrm{mL}$ \\
\hline & 5 & $40 / \mathrm{M}$ & $\mathrm{fT}_{3}, 6.0 \mathrm{pg} / \mathrm{mL} ; \mathrm{fT}_{4}, 1.4 \mathrm{pg} / \mathrm{mL}, \mathrm{TSH}, 6.34 \mu \mathrm{U} / \mathrm{mL}$ \\
\hline \multirow[t]{8}{*}{ Gonadotropin-subunit-positive adenoma } & 1 & $69 / \mathrm{M}$ & FSH, $10.6 \mathrm{mIU} / \mathrm{mL}$ \\
\hline & 2 & $60 / \mathrm{M}$ & FSH, $15.9 \mathrm{mIU} / \mathrm{mL}$ \\
\hline & 3 & $29 / \mathrm{M}$ & FSH, $15.5 \mathrm{mIU} / \mathrm{mL}$ \\
\hline & 4 & $61 / F$ & FSH, $34.9 \mathrm{mIU} / \mathrm{mL}$ \\
\hline & 5 & $37 / \mathrm{M}$ & FSH, $15.7 \mathrm{mIU} / \mathrm{mL}$ \\
\hline & 6 & $48 / \mathrm{F}$ & $\mathrm{FSH}, 12.6 \mathrm{mIU} / \mathrm{mL}$ \\
\hline & 7 & $53 / \mathrm{M}$ & FSH, $32.8 \mathrm{mIU} / \mathrm{mL}$ \\
\hline & 8 & $51 / \mathrm{M}$ & FSH, $11.5 \mathrm{mIU} / \mathrm{mL}$ \\
\hline \multirow[t]{5}{*}{ Null cell adenoma } & 1 & $59 / \mathrm{M}$ & FSH, $2.3 \mathrm{mIU} / \mathrm{mL}$ \\
\hline & 2 & $62 / \mathrm{M}$ & $\mathrm{FSH}, 6.4 \mathrm{mIU} / \mathrm{mL}$ \\
\hline & 3 & $60 / \mathrm{M}$ & FSH, $10.0 \mathrm{mIU} / \mathrm{mL}$ \\
\hline & 4 & $71 / \mathrm{F}$ & FSH, $3.5 \mathrm{mIU} / \mathrm{mL}$ \\
\hline & 5 & $57 / \mathrm{M}$ & FSH, $2.5 \mathrm{mIU} / \mathrm{mL}$ \\
\hline
\end{tabular}

Normal plasma levels: GH, $<5$ ng/mL; IGF-1, 106-398 ng/mL; PRL $<20$ ng/mL; ACTH, 7-60 pg/mL at 9:00 a.m.; UFC (urinary free cortisol), 34-208 $\mu \mathrm{g} /$ day; $\mathrm{fT}_{3}$ (free $\mathrm{T}_{3}$ ), $2.4-4.3 \mathrm{pg} / \mathrm{mL} ; \mathrm{fT}_{4}$ (free $\mathrm{T}_{4}$ ), $0.74-1.8 \mathrm{ng} / \mathrm{mL} ; \mathrm{TSH},<5 \mu \mathrm{U} / \mathrm{mL} ; \alpha$-subunit, $0.1-1.3 \mathrm{mg} / \mathrm{L} ; \mathrm{FSH},(\mathrm{male}), 1-11 \mathrm{mI} / \mathrm{mL}$. 
polyclonal antibody (Santa Cruz, CA) was applied at dilution 1:100 for 60 minutes. To detect the expression of Pit-1, microwave was introduced for $10 \mathrm{~min}$ utes at $100^{\circ} \mathrm{C}$ in $0.01 \mathrm{~mol} / \mathrm{L}$ citrate buffer, $\mathrm{pH} 6.0$, for antigen retrieval, and goat polyclonal antibody against Pit-1 (Santa Cruz, CA) was applied at dilution 1:100 for 60 minutes. The section was rinsed in phosphate buffered saline and incubated with biotinylated anti-goat immunoglobulin (Vector Laboratories, UK). After incubation with $\mathrm{ABC}$, the reaction was visualized by incubation with $3,3^{\prime}$ diaminobenzidine tetrahydrochloride for $3 \mathrm{~min}$ utes, which resulted in a brown color.

\section{Reverse Transcription Polymerase Chain Reaction}

Total RNA extraction was performed by the single-step method (TRIzol reagent kit, Life Technologies, Gaithersburg, MD) from 38 pituitary adenomas, and total RNA was treated by Deoxyribonuclease I (Life Technologies). First-standard complementary DNA (cDNA) was prepared from total RNA with Deoxyribonuclease I treatment using a T-Primed First-Stand kit (Pharmacia Biotech Inc, USA). The RT reaction was performed at $37^{\circ} \mathrm{C}$ for 60 minutes in a final volume of $50 \mu \mathrm{L}$, with $5 \mu \mathrm{g}$ total RNA.

For PCR, the following oligonucleotide primers were used to identify human GATA-2: upstream, 5'-CCC TAA GCA GCG CAG CAA GAC-3', and downstream, 5'-GAT GAG TGG TCG GTT CTG GCC-3'. This generated an RT-PCR product of $163 \mathrm{bp}$. These primers were previously reported by Dorfman et al. (19). We also examined the expression of Pit-1, using oligonucleotide primers as follows: upstream, 5'-ACA GCT GCT GAT TTC AAG CA-3', and downstream, 5'-ACA AAG CTC CTA CTT GCT CA-3'. This generated an RT-PCR product of $304 \mathrm{bp}$. The PCR was carried out in $100-\mu \mathrm{L}$ final reaction volumes containing $1 \mu \mathrm{L}$ of RT reaction products as template DNA, corresponding to cDNA synthesized from 500 ng of total RNA, $1 \times$ PCR buffer II, $1.0 \mathrm{mmol} / \mathrm{L}$ of $\mathrm{MgCl}_{2}, 0.2 \mathrm{mmol} / \mathrm{L}$ of each deoxynucleotide, 0.4 $\mu \mathrm{mol} / \mathrm{L}$ of each upstream and downstream primer, and 2.5 U of AmpliTaq Gold (Perkin-Elmer). Programmable temperature cycling (Perkin-Elmer/GeneAmp PCR System 9700, Norwalk, CT) was performed with the following cycle profile: $95^{\circ} \mathrm{C}$ for 10 minutes as an initial denaturing step, followed by $95^{\circ} \mathrm{C}$ for 1 minute as an amplification step and by $61^{\circ} \mathrm{C}$ for 1 minute as an annealing and extension (40 cycles) for human GATA-2 or by $56^{\circ} \mathrm{C}$ for 1 minute as an annealing and extension (40 cycles) for human Pit-1. After the last cycle, the elongation step was done at $72^{\circ} \mathrm{C}$ for 10 minutes. The samples of the reaction products ( $8 \mu \mathrm{L}$ each) were subjected to electrophoresis in $2 \%$ agarose gels with ethidium bromide and were photographed under ultraviolet light.

\section{RESULTS}

\section{Immunohistochemical Analysis}

The clinical profiles of each patient with pituitary tumor were as summarized in Table 1. Immunostaining of GATA-2 and Pit-1 protein were performed in all pituitary tumors. Immunohistochemical detection of GATA-2 protein was detected in 12 of 38 cases $(31.6 \%)$ of human pituitary adenomas and was expressed in the nuclei of the adenoma cells. The results of the immunohistochemical examination of the different types of adenoma are summarized in Table 2. GATA-2 protein was detected in eight of eight cases $(100 \%)$ with Gn-supositive adenomas and in four of five cases $(80 \%)$ with TSH-secreting adenomas, but its incidence was null in the other types of adenomas. Pit-1 protein was detected in 4 of 5 TSH-secreting adenomas, in 10 of $10 \mathrm{GH}$-secreting adenomas, and in 6 of 6 PRL-secreting adenomas.

\section{RT-PCR Analysis}

RT-PCR analysis of GATA-2 and Pit-1 was also performed in all 38 pituitary adenomas. The results of RT-PCR are shown in Figure 1. The GATA-2 PCR products were detected at $163 \mathrm{bp}$, and Pit-1 PCR products were detected at $304 \mathrm{bp}$ by ethidium bromide staining. The results of the RT-PCR analysis of the different types of adenoma are summarized in Table 3. GATA-2 was detected all of Gn-su-positive adenomas and in four of five TSH-secreting adenomas (Fig. 2, A-B). Pit-1 was detected in all of the GH-secreting adenomas $(n=10)$, in five of six PRL-secreting adenomas, and in four of five TSHsecreting adenomas. Three GH-secreting adenomas and two nonfunctioning adenomas that were negative for GATA-2 protein by immunohistochemistry expressed GATA-2 mRNA by RT-PCR, and two Gnsu-positive adenomas that were negative for Pit-1 protein expressed Pit-1 mRNA by RT-PCR.

We performed the sequence analysis of RT-PCR products amplified from two Gn-su-positive adenomas (Cases 7 and 8) and two TSH-secreting adenomas (Cases 1 and 4). These sequencing data revealed no mutation in all cases, and the detected sequences were identical to those of GATA-2 and Pit-1 (data not shown).

\section{DISCUSSION}

Several transcription-regulating proteins have been identified in the adenohypophysis and have been implicated as key elements in the definition of 


\begin{tabular}{|c|c|c|c|c|c|c|c|c|c|c|c|c|}
\hline \multirow{2}{*}{$\begin{array}{c}\text { Case } \\
\text { No. }\end{array}$} & \multirow{2}{*}{ Age $(y) / S e x$} & \multicolumn{9}{|c|}{ Immunohistochemistry } & \multicolumn{2}{|c|}{ RT-PCR } \\
\hline & & GH & PRL & ACTH & $\mathrm{FSH} \beta$ & $\mathrm{LH} \beta$ & $\mathrm{TSH} \beta$ & $\alpha$-SU & GATA-2 & Pit-1 & GATA-2 & Pit-1 \\
\hline \multicolumn{13}{|c|}{ Acromegaly } \\
\hline 1 & $38 / \mathrm{F}$ & +++ & +++ & - & - & - & - & - & - & ++ & - & + \\
\hline 2 & $59 / \mathrm{F}$ & ++ & + & - & - & - & - & - & - & + & - & + \\
\hline 3 & $45 / \mathrm{F}$ & +++ & +++ & - & - & - & - & + & - & +++ & - & + \\
\hline 4 & $46 / \mathrm{M}$ & +++ & +++ & - & - & - & - & - & - & ++ & - & + \\
\hline 5 & $48 / \mathrm{F}$ & +++ & +++ & - & - & - & - & ++ & - & +++ & - & + \\
\hline 6 & $30 / \mathrm{M}$ & +++ & +++ & - & - & - & - & - & - & + & - & + \\
\hline 7 & $52 / \mathrm{M}$ & +++ & ++ & - & - & - & - & + & - & ++ & - & + \\
\hline 8 & $35 / \mathrm{M}$ & +++ & +++ & - & - & - & - & - & - & + & + & + \\
\hline 9 & $55 / \mathrm{M}$ & +++ & +++ & - & - & - & - & + & - & + & + & + \\
\hline 10 & $51 / \mathrm{M}$ & +++ & +++ & - & - & - & - & ++ & - & ++ & + & + \\
\hline \multicolumn{13}{|c|}{ PRL-secreting adenoma } \\
\hline 1 & $20 / \mathrm{F}$ & - & +++ & - & - & - & - & - & - & ++ & - & + \\
\hline 2 & $19 / \mathrm{F}$ & - & ++ & - & - & - & - & - & - & - & - & - \\
\hline 3 & $23 / \mathrm{F}$ & - & +++ & - & - & - & - & - & - & ++ & - & + \\
\hline 4 & $31 / \mathrm{M}$ & - & +++ & - & - & - & - & - & - & +++ & - & + \\
\hline 5 & $24 / \mathrm{F}$ & - & +++ & - & - & - & - & - & - & +++ & - & + \\
\hline 6 & $37 / \mathrm{F}$ & - & +++ & - & - & - & - & - & - & ++ & - & + \\
\hline \multicolumn{13}{|c|}{ Cushing's disease } \\
\hline 1 & $55 / \mathrm{M}$ & - & - & +++ & - & - & - & - & - & - & - & - \\
\hline 2 & $28 / \mathrm{F}$ & - & - & +++ & - & - & - & - & - & - & - & - \\
\hline 3 & $44 / \mathrm{F}$ & - & - & +++ & - & - & - & - & - & - & - & - \\
\hline 4 & $29 / M$ & - & - & +++ & - & - & - & - & - & - & - & - \\
\hline \multicolumn{13}{|c|}{ TSH-secreting adenoma } \\
\hline 1 & $53 / \mathrm{F}$ & - & - & - & - & - & + & + & +++ & ++ & + & + \\
\hline 2 & $41 / \mathrm{M}$ & + & - & - & - & - & + & - & - & +++ & + & + \\
\hline 3 & $35 / \mathrm{F}$ & - & - & - & - & - & ++ & ++ & ++ & ++ & + & + \\
\hline 4 & $28 / \mathrm{F}$ & - & - & - & - & - & +++ & - & ++ & ++ & + & + \\
\hline 5 & $40 / \mathrm{M}$ & - & - & - & - & - & +++ & +++ & +++ & - & + & + \\
\hline \multicolumn{13}{|c|}{ Gonadotropin-subunit-positive adenomas } \\
\hline 1 & $69 / \mathrm{M}$ & - & - & - & + & - & - & + & ++ & - & + & - \\
\hline 2 & $60 / \mathrm{M}$ & - & - & & ++ & - & - & - & +++ & - & + & - \\
\hline 3 & $29 / M$ & - & - & - & + & + & - & ++ & ++ & - & + & - \\
\hline 4 & $61 / \mathrm{F}$ & - & - & - & ++ & - & - & - & ++ & - & + & - \\
\hline 5 & $37 / \mathrm{M}$ & - & - & - & ++ & + & - & - & + & - & + & - \\
\hline 6 & $48 / \mathrm{F}$ & - & - & - & ++ & - & - & ++ & +++ & - & + & - \\
\hline 7 & $53 / \mathrm{M}$ & - & - & - & ++ & - & - & + & ++ & - & + & + \\
\hline 8 & $51 / \mathrm{M}$ & - & - & - & +++ & + & - & + & ++ & - & + & + \\
\hline \multicolumn{13}{|c|}{ Null cell adenoma } \\
\hline 1 & $59 / \mathrm{M}$ & - & - & - & - & - & - & - & - & - & - & - \\
\hline 2 & $62 / \mathrm{M}$ & - & - & - & - & & - & - & - & - & - & - \\
\hline 3 & $60 / \mathrm{M}$ & - & - & - & - & - & - & - & - & - & + & - \\
\hline 4 & $71 / \mathrm{F}$ & - & - & - & - & - & - & - & - & + & + & + \\
\hline 5 & $57 / \mathrm{M}$ & - & - & - & - & - & - & - & - & - & - & - \\
\hline
\end{tabular}

cell-specific phenotypes and the regulation of hormone gene expression. In pituitary adenomas, transcription factors also regulate various genes that play important roles in functional differentiation. For example, Pit-1, a 291-amino acid protein that belongs to the homeobox family of developmental regulatory proteins, was detected in GH-, PRL- (5$11)$, and TSH-producing adenomas $(12,20)$. Synergic interaction involving Pit-1 with other transcription factors on a variety of pituitary hormone genes has been reported. For example, cooperation of Pit-1 with Oct-1 (21) and estrogen receptor $(22,23)$ activates the PRL promoter, and on the growth hormone gene promoter, Pit-1 synergizes with $\mathrm{Zn}-15$ (24) and thyroid hormone receptor (25).

The GATA families of transcription factors are also tissue specific in their expressions. Six members of the GATA family have been identified in vertebrates $(26,27)$. These factors bind to a DNA consensus sequence, (T/A)GATA(A/G), using a highly conserved DNA-binding domain composed of amino- and carboxy-terminal zinc fingers (28, 29). During the functional differentiation of adenohypophysis, functional interaction between Pit-1 and zinc finger protein has been reported. In transgenic mouse pituitary, zinc finger protein 15 binds to the element located between two Pit-1 response elements and constitutes an important component of the combination code that underlies the effective expression of the GH gene (24). Transcription factor GATA-2 contains two copies of a highly conserved zinc finger domain and plays unique roles at an early stage of hematopoietic differentiation $(26,30$ 32). Recently, Steger et al. (16) have demonstrated that GATA transcription factor plays a role in pituitary $\alpha$-subunit expression. They have demon- 

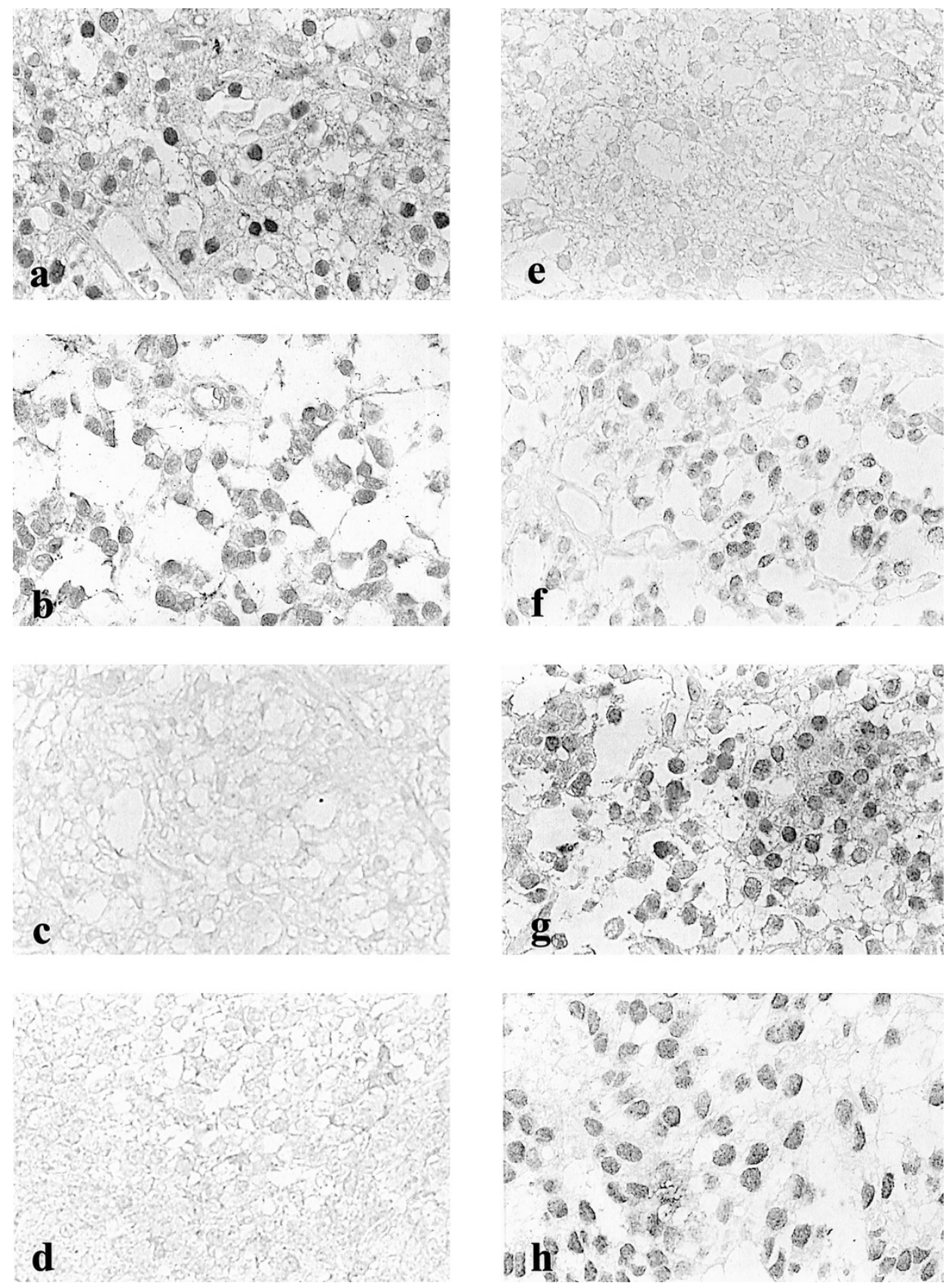

FIGURE 1. Immunohistochemical detection of GATA-2 (A-D) and Pit-1 (E-H) protein. Gonadotropin-subunit-positive (Gn-su-positive) adenoma (A) and thyroid-stimulating hormone (TSH)-secreting adenoma (B) have diffuse and strong nuclear reactivity for GATA-2 protein. Pit-1 protein is also detected in the nuclei of TSH-secreting adenoma (F), growth hormone (GH)-secreting adenoma (G), and prolactin (PRL)-secreting adenoma (H). On the other hand, no GATA-2 protein was detected in GH-secreting (C) and PRL-secreting (D) adenomas. No Pit-1 protein was detected in Gn-supositive adenoma (E) for Pit-1.

strated that both GATA-2 and GATA-3 are present in placental trophoblasts, whereas both GATA-2 and a GATA-4-related factor are present in pituitary gonadotropes. David et al. (17) have reported functional synergic and physical interaction between GATA-2 and Pit-1 in pituitary thyrotropes. They demonstrated that both GATA-2 and Pit-1 could bind independently to the $\mathrm{P} 1$ region of the mouse $\mathrm{TSH} \beta$ promoter in thyrotrope cells and could functionally synergize to activate $\mathrm{TSH} \beta$ promoter activity. Jermy et al. (15) have also reported the recipro- cal interactions of Pit-1 and GATA-2 in mouse anterior pituitary. Their data suggested that ventral expression of GATA-2 directly or indirectly suppresses Pit-1 gene expression and induces the entire set of transcription factors that are typical of the gonadotrope cell type differentiation. Conversely, the absence of GATA-2 dorsally, Pit-1 was induced, and cell types were converted to somatotrope/lactotrope. In the differentiation of thyrotrope, they hypothesized that the level of GATA-2 expression is below to inhibit the activation of the Pit-1 gene and 


\begin{tabular}{|c|c|c|c|c|c|}
\hline \multirow{2}{*}{ Diagnosis } & \multirow{2}{*}{$\begin{array}{l}\text { Number } \\
\text { Studied }\end{array}$} & \multicolumn{2}{|c|}{ GATA-2, $n$ (\% positive) } & \multicolumn{2}{|c|}{ Pit-1, $n$ (\% positive) } \\
\hline & & Protein & mRNA & Protein & mRNA \\
\hline GH-secreting adenomas & 10 & $0(0)$ & $3(30)$ & $10(100)$ & $10(100)$ \\
\hline PRL-secreting adenomas & 6 & $0(0)$ & $0(0)$ & 5 (83.7) & $5(83.7)$ \\
\hline ACTH-secreting adenomas & 4 & $0(0)$ & $0(0)$ & $0(0)$ & $0(0)$ \\
\hline TSH-secreting adenomas & 5 & $4(80)$ & $5(100)$ & $4(80)$ & $5(100)$ \\
\hline Nonfunctioning adenomas & 5 & $0(0)$ & $2(40)$ & $1(20)$ & $1(20)$ \\
\hline Gonadotropin-subunit-positive adenomas & 8 & $8(100)$ & $8(100)$ & $0(0)$ & $2(25)$ \\
\hline Total & 38 & 12 (31.6) & $18(47.4)$ & $20(52.6)$ & $23(60.5)$ \\
\hline
\end{tabular}

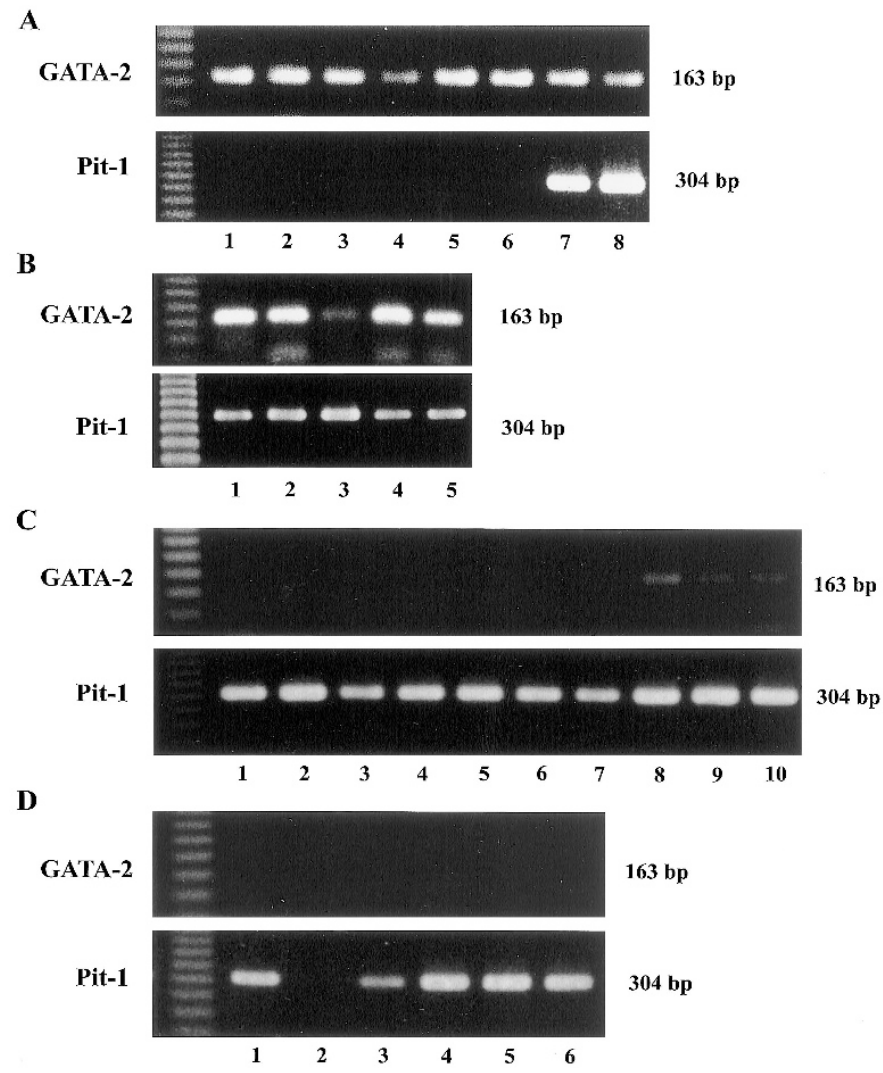

FIGURE 2. Reverse transcription polymerase chain reaction (PCR) of human pituitary adenomas for GATA-2 and Pit-1 mRNA. All of the gonadotropin-subunit-positive (Gn-su-positive) adenomas $(n=8)$ and thyroid-stimulating hormone (TSH)-secreting adenomas $(n=5)$ have highlevel expression of GATA-2 mRNA. Pit-1 mRNA was detected in all of the growth hormone (GH)-secreting adenomas $(n=10)$ and TSH-secreting adenomas $(n=5)$ and in five of six prolactin (PRL)-secreting adenomas. A, PCR amplification of GATA-2 and Pit-1 of Gn-su-positive adenomas. B, TSH-secreting adenomas. C, GH-secreting adenomas. D, PRL-secreting adenomas.

that coexpression of GATA-2 and Pit-1 can induce the entire set of transcription factors that are typical of thyrotrope cell type differentiation.

In our studies of human pituitary adenomas, most of the Gn-su-positive adenomas and TSHsecreting adenomas were positive for GATA-2, and most of TSH, PRL, and GH-secreting adenomas were positive for Pit-1. These results suggested that GATA-2 contributes to the functional expression and the differentiation of Gn-su-positive adenomas and TSH-secreting adenomas. In the situation with high expression of GATA-2, Pit-1 gene expression is suppressed, and cell types are terminally differentiated to Gn-su-positive adenomas. And the interaction between GATA- 2 and Pit- 1 can lead to gene- specific action and differentiation of TSH-secreting adenomas. Thus, GATA-2, which earlier in development is required for the expansion of hematopoietic precursors (33) and the development of the placental trophoblast (34) and urogenital system (35), also plays a critical role in pituitary cell type determination (15).

In summary, GATA-2 is mainly expressed in Gnsu-secreting adenomas and in TSH-secreting adenomas, whereas Pit-1 is expressed mainly in GH, PRL, and TSH-secreting adenomas. Our results suggest that GATA-2 contributes to the functional expression and the differentiation of the Gn-susecreting adenomas and that interaction with GATA-2 and Pit-1 can lead to gene-specific action 
and differentiation to TSH-secreting adenomas. We suspected that these transcriptional factors as well as transcriptional interaction would prove to be prototype-specific action in the development of pituitaries and pituitary adenomas.

\section{REFERENCES}

1. Eagleson GW, Harris WA. Mapping of the presumptive brain regions in the neural plate of Xenopus laevis. J Neurobiol 1990;21:427-40.

2. Ericson J, Norlin S, Jessell T, Edlund T. Integrated FGF and BMP signaling controls the progression of progenitor cell differentiation and the emergence of pattern in the embryonic anterior pituitary. Development 1998;125:1005-15.

3. Takuma N, Sheng HZ, Furuta Y, Ward JM, Sharma K, Hogan BL, et al. Formation of Rathke's pouch requires dual induction from the diencephalons. Development 1998;125:483540 .

4. Treier M, Gleiberman AS, O'Connell SM, Szeto DP, McMahon JA, McMahon AP, et al. Multistep signaling requirement for pituitary organogenesis in vivo. Genes Dev 1998;12:1691704.

5. Asa SL, Puy LA, Lew AM, Sundmark VC, Elsholtz HP. Cell type-specific expression of the pituitary transcription activator pit-1 in the human pituitary and pituitary adenomas. J Clin Endocrinol Metab 1993;77:1275-80.

6. Delhase M, Vergoni P, Maulur A, Velkeniers B, Tengels E, Trouillas J, et al. Pit-1/GHF-1 expression in pituitary adenomas: further analogy between human adenomas and rat SMtTW tumors. J Mol Endocrinol 1993;11:129-39.

7. Friend KE, Chiou YK, Laws ER Jr, Lopes MBS, Shupnik MA. Pit-1 messenger ribonucleic acid is differentially expressed in human pituitary adenomas. J Clin Endocrinol Metab 1993; 77:1281-6.

8. Hoggard N, Callaghan K, Lenz A, Davis JRE. Expression of Pit-1and related proteins in diverse human pituitary adenomas. J Mol Endocrinol 1993;11:283-90.

9. Sanno N, Inada K, Utsunomiya H, Umemura S, Itoh Y, Matsuno A, et al. Expression of pit-1 product in human pituitaries: histochemical studies using an antibody against synthetic human pit-1 protein. Med Sci Res 1994a;22:685-7.

10. Camper SA, Ssunders TL, Katz RW, Reeves RH. The Pit-1 transcription factor gene is a candidate for the murine Snell dwarf mutation. Genomics 1990;8:586-90.

11. Simmons DM, Voss JW, Ingraham HA, Holloway JW, Broide RS, Rosenfeld MG, et al. Pituitary cell phenotypes involve cellspecific Pit-1 mRNA translation and synergistic interaction with other transcription factors. Genes Dev 1990;4:695-711.

12. Li S, Crenshaw EB, Rawson EJ, Simmons DM, Swanson LW, Rosenfeld MG. Dwarf locus mutant lacking three pituitary cell types result from mutations in the POU-domain gene Pit-1. Nature 1990;347:528-33.

13. Therrien M, Drouin J. Cell-specific helix-loop-helix factor required for pituitary expression of the proopiomelanocortin gene. Mol Cell Biol 1993;13:2342-53.

14. Poulin G, Turgeon B, Drouin J. Neuro D1/2 contributes to cell-specific transcription of the proopiomelanocortin gene. Mol Cell Biol 1997;17:6673-82.

15. Jermy SD, Shawn MO, Sarah EF, Mathias T, Anatoli S, Daniel PS, et al. Reciprocal interaction of Pit1 and GATA2 mediate signaling gradient-induced determination of pituitary cell types. Cell 1999;97:587-98.

16. David JS, Jonathan HH, Pamela LM. GATA-binding proteins regulate the human gonadotropin $\alpha$-subunit gene in the placenta and pituitary gland. Mol Cell Biol 1994;14:5592602.
17. David FG, Suzanne RL, Lewis BR, Bryan RH, Andrew J, Michael TM, et al. Pit-1 and GATA-2 interact and functionally cooperate to activate the thyrotropin $\beta$-subunit promoter. J Biol Chem 1997;272:24339-47.

18. Sanno N, Teramoto A, Osamura RY. Clinical and cytofunctional classification of pituitary adenomas: proposal of a new classification. Acta Neurochir 1996;138:1186-92.

19. Dorfman DM, Wilson DB, Bruns GA, Orkin SH. Human transcription factor GATA-2. Evidence for regulation of preproendothelin-1 gene expression in endothelial cells. J Biol Chem 1992;267:1279.

20. Sanno N, Teramoto A, Matsuno A, Inada K, Itoh J, Osamura RY. Clinical and immunohistochemical studies on TSHsecreting pituitary adenoma: its multihormonality and expression of pit-1. Mod Pathol 1994;7:893-9.

21. Voss JW, Wilson L, Rosenfeld MG. POU-domain proteins Pit-1 and Oct-1 interact to form a heteromeric complex and can cooperate to induce expression of the prolactin promoter. Genes Dev 1991;5:1309-20.

22. Day RN, Koike S, Sakai M, Muramatsu M, Maurer RA. Both Pit-1 and the estrogen receptor are required for estrogen responsiveness of rat prolactin gene. Mol Endocrinol 1990; 4:1964-71.

23. Simmons DM, Voss JW, Ingraham HA, Holloway JM, Broide RS, Rosenfeld MG, et al. Pituitary cell phenotypes involve cell-specific Pit-1 mRNA translation and synergistic interaction with other classes of transcription factors. Genes Dev 1990;4:695-711.

24. Lipkin SM, Naar AM, Kalla KA, Sack RA, Rosenfeld MG. Identification of a novel zinc finger protein binding a conserved element critical for Pit-1-dependent growth hormone gene expression. Genes Dev 1993;7:1674-87.

25. Chang W, Zhou W, Theill LE, Baxter JD, Schaufele F. An activation function in Pit-1 required selectively for synergistic transcription. J Biol Chem 1996;271:17733-8.

26. Evans T, Felsenfeld G. The erythroid-specific transcription factor Eryf1: a new finger protein. Cell 1989;58:877-85.

27. Jacques JT, Robert SV. GATA factors differentially activate multiple gonadal promoters through conserved GATA regulatory elements. Endocrinology 2001;142:977-86.

28. Trainor CD, Omichinski JG, Vandergon TL, Gronenborn AM, Clore GM, Felsenfeld G. A palindromic regulatory site within vertebrate GATA-1 promoters require both zinc fingers of the GATA-1 DNA-binding domain for high-affinity interaction. Mol Cell Biol 1996;16:2238.

29. Tsang AP, Visvader JE, Turner CA, Fujiwara Y, Yu C, Weiss $\mathrm{MJ}$, et al. FOG, a multiple zinc finger protein, acts as a cofactor for transcription factor GATA-1 in erythroid and megakaryocytic differentiation. Cell 1997;90:109.

30. Leonard M, Brice M, Engel JD, Papayannopoulou T. Dynamic transcription factor expression during erythroid differentiation. Blood 1993;82:1071-9.

31. Yamamoto M, Ko LJ, Leonard MW, Beug H, Orkin SH, Engel JD. Activity and tissue-specific expression of the transcription factor NF-E1 multigene family. Genes Dev 1990;4:1650-62.

32. Molkentin JD, Lin Q, Duncan SA, Olson EN. Requirement of the transcription factor GATA4 for heart tube formation and ventral morphogenesis. Genes Dev 1997;11:1061-72.

33. Tsai FY, Keller G, Kuo FC, Weiss M, Chen J, Rosenblatt M, et al. An early hematopoietic defect in mice lacking the transcription factor GATA-2. Nature 1994;371:221-6.

34. Ma GT, Roth ME, Groskopf JC, Tsai FY, Orkin SH, Grosveld F, et al. GATA-2 and GATA-3 regulate trophoblast-specific gene expression in vivo. Development 1997;124:907-14.

35. Zuou Y, Lim KC, Onodera K, Takahashi S, Ohta J, Minegishi $\mathrm{N}$, et al. Rescue of the embryonic lethal hematopoietic defect reveals a critical role for GATA-2 in urogenital development. EMBO J 1998;17:6689-700. 